\title{
Analysis of the Current-voltage Curves of a $\mathrm{Cu}(\mathrm{In}, \mathrm{Ga}) \mathrm{Se}_{2}$ Thin-film Solar Cell Measured at Different Irradiation Conditions
}

\author{
Kyu-Seok Lee ${ }^{1 *}$, Yong Duck Chung ${ }^{1}$, Nae Man Park ${ }^{1}$, Dae Hyung Cho ${ }^{1}$, \\ Kyung Hyun Kim', and Jeha Kim ${ }^{1}$ \\ ${ }^{I}$ Thin Film Photovoltaic Technology Research Team, Electronics and Telecommunications Research \\ Institute, Daejeon 305-700, Korea
}

Seong Jun $\mathrm{Kim}^{2}$, Yeongho $\mathrm{Kim}^{2}$, and Sam Kyu Noh ${ }^{2,3}$

${ }^{2}$ Nano Electronics Engineering Part, University of Science and Technology, Daejeon 305-333, Korea

${ }^{3}$ Nano Evaluation Center, Korea Research Institute of Standards and Science, Daejeon 305-340, Korea

(Received October 13, 2010 : revised November 16, 2010 : accepted November 19, 2010)

\begin{abstract}
We analyze the current density - voltage $(\mathrm{J}-\mathrm{V})$ curve of a $\mathrm{Cu}(\mathrm{In}, \mathrm{Ga}) \mathrm{Se}_{2}$ (CIGS) thin-film solar cell measured at different irradiation power densities. For the solar-cell sample investigated in this study, the fill factor and power conversion efficiency decreased as the irradiation power density (IPD) increased in the range of 2 to 5 sun. Characteristic parameters of solar cell including the series resistance $\left(r_{s}\right)$, the shunt resistance $\left(\mathrm{r}_{\mathrm{sh}}\right)$, the photocurrent density $\left(\mathrm{J}_{\mathrm{L}}\right)$, the saturation current density $\left(\mathrm{J}_{\mathrm{s}}\right)$ of an ideal diode, and the coefficient $\left(\mathrm{C}_{\mathrm{s}}\right)$ of the diode current due to electron-hole recombination via ionized traps at the $\mathrm{p}-\mathrm{n}$ interface are determined from a theoretical fit to the experimental data of the $\mathrm{J}-\mathrm{V}$ curve using a two-diode model. As IPD increased, both $r_{s}$ and $r_{s h}$ decreased, but $C_{s}$ increased.
\end{abstract}

Keywords: $\mathrm{Cu}(\mathrm{In}, \mathrm{Ga}) \mathrm{Se}_{2}$, Thin film, Solar cell, J-V curve

OCIS codes : (310.6845) Thin film devices and applications; (040.5350) Photovoltaic

\section{INTRODUCTION}

Recently, the $\mathrm{Cu}(\mathrm{In}, \mathrm{Ga}) \mathrm{Se}_{2}$ (CIGS) thin-film solar cell has been the subject of intensive research and development in the photovoltaic industry [1-6]. CIGS has a great potential for solar cells with high power-conversion efficiencies. The record efficiency for a small-size CIGS thin-film solar cell is about $20 \%$ [1]. CIGS solar cells can also be fabricated on a wide-area substrate cost-effectively [3-4]. These advantages offer CIGS a possibility to achieve the grid parity to compete with conventional technologies. In order to fabricate a highly efficient CIGS solar cell, it is prerequisite to have knowledge of the properties of material and the characteristic circuit parameters of the solar cell.

In particular, the diode current (or the dark current), the series resistance, and the shunt resistance have significant effects on the performance of a solar cell [7]. The diode current is generated by electron-hole recombination occurring at the $p$-n interface or in the quasi-neutral regions of p-type and n-type semiconductors. The series resistance and the shunt resistance are known to be affected by various properties such as the quality of materials constituting the solar cell and the grid design of solar-cell modules. A solar cell that has a low series resistance, a large shunt resistance and a small coefficient of the diode current yields a high fill factor in its current density - voltage $(\mathrm{J}-\mathrm{V})$ curve and therefore exhibits a high value of the powerconversion efficiency. These parameters can be estimated from a theoretical fit to the $\mathrm{J}-\mathrm{V}$ curve of the solar cell [8-9]. Two simple approaches are lumped circuit models using one diode or two diodes. The one-diode model incorporates the ideality factor of diode to account for the effect of electron-hole recombination which occurs at the p-n interface, whereas the two-diode model handles it using a separate component of diode current. The two-diode model has been known to be more accurate than the one-diode

\footnotetext{
*Corresponding author: kyulee@etri.re.kr

Color versions of one or more of the figures in this paper are available online.
} 
model [8].

The purpose of this study is to investigate the performance of CIGS thin-film solar cells in concentrated photovoltaic applications. In the past years, there have been some studies on using CIGS solar cells as power generators which might be operated under solar irradiation with a power density less than one sun [10]. However, to the best of authors' knowledge, few reports have been available on the performance of CIGS thin-film solar cells under solar irradiation with a power density higher than one sun. In this report, we analyze the $\mathrm{J}-\mathrm{V}$ curve of a CIGS thin-film solar cell under irradiation of solar power densities from 1.5 to 5.0 sun. Using a lumped circuit model with two diodes, we found that both the series resistance and the shunt resistance tended to decrease as irradiation power density (IPD) increased. We also found that a component of diode current which is contributed by electron-hole recombination through traps at the $p$ - $n$ interface to the diode current tended to increase with IPD.

\section{STRUCTURE OF SOLAR CELL}

The structure of the CIGS thin-film solar cell prepared for this study is shown in Fig. 1. A Molybdenum film was coated as the back electrode on a soda-lime glass substrate, and CIGS with a thickness of about $2 \mu \mathrm{m}$ was deposited in a three-step evaporation process. Subsequently, CdS with a thickness of about $50 \mathrm{~nm}$ was formed by chemical vapor deposition (CBD), and intrinsic $\mathrm{ZnO}$ and indium-tine-oxide were deposited. Finally, fabrication of the current-collecting grid completed the device. The solar cell for this study had no anti-reflection coating. Fabrication of the solar cell is detailed elsewhere [11].

\section{J - V MEASUREMENTS}

A solar simulator was used as the light source in $\mathrm{J}-\mathrm{V}$ measurements. The solar simulator provided an irradiation power density of $1 \mathrm{~kW} / \mathrm{m}^{2}(\mathrm{AM} 1.5)$ at $25^{\circ} \mathrm{C}$. The solar cell was mounted on a sample holder installed at a height

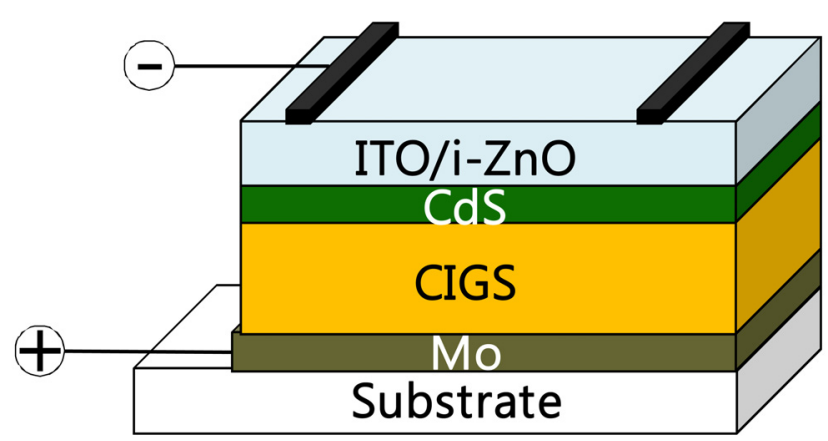

FIG. 1. Schematic of the CIGS thin-film solar cell.
$7.5 \mathrm{~cm}$ above an optical table. A power meter that is sensitive to the ultraviolet light was put in a position of $1.5 \mathrm{~cm}$ above the solar cell, and a convex lens was put above the power meter. We observed that the power of solar irradiation I is related to the distance between the lens and the power meter $\Delta \mathrm{y}$ within the focal length in the form $\mathrm{I}=\mathrm{I}_{0}+\mathrm{k}(\Delta \mathrm{y})^{2}$, where $\mathrm{I}_{0}$ and $\mathrm{k}$ are constants. This relation allowed us to find the position of lens for a desired power density on the solar cell. However, because the lens distorted the spectrum of lights passing through it, the spectra of the light through the lens was different from that without the lens. Therefore, in our discussion, we will exclude the $\mathrm{J}-\mathrm{V}$ curve measured at one-sun power density from comparison with others measured at different power densities. Since each measurement took about three seconds, we believe that an increase in the solar-cell temperature during each measurement did not change significantly the characteristic parameters of the solar cell.

\section{TWO-DIODE MODEL}

In order to determine the characteristic parameters of the solar cell, we employ a two-diode model whose equivalent circuit is shown in Figure 2. With this model, the $\mathbf{J}$ - $\mathrm{V}$ curve can be obtained from the following equation:

$$
\mathrm{V}+\mathrm{Jr}_{\mathrm{s}}+\mathrm{r}_{\mathrm{sh}}\left(\mathrm{J}-\mathrm{J}_{\mathrm{L}}+\mathrm{J}_{\mathrm{d} 1}+\mathrm{J}_{\mathrm{d} 2}\right)=0,
$$

where $r_{s}$ and $r_{s h}$ are the series resistance and the shunt resistance, respectively, in the unit of $\mathrm{V} / \mathrm{J}$. $\mathrm{J}_{\mathrm{L}}$ is the density of the photocurrent generated in the solar cell. $\mathrm{J}_{\mathrm{d} 1}$ represents the diode current due to electron-hole recombination in the quasi-neutral region, and it is given as

$$
\mathrm{J}_{\mathrm{d} 1}=\mathrm{J}_{\mathrm{s}}\left(\mathrm{e}^{\frac{\mathrm{q} \mathrm{V}^{\prime}}{\mathrm{kT}}}-1\right),
$$

where $\mathrm{V}^{\prime}=\mathrm{V}+\mathrm{Jr}_{\mathrm{s}}$ is the applied bias across the depletion region of the solar cell, q denotes the fundamental electric charge, $\mathrm{k}$ is the Boltzmann constant, and $\mathrm{T}$ is the temperature in Kelvin. $J_{\mathrm{s}}$ is the saturation current density of an ideal diode. $\mathrm{J}_{\mathrm{d} 2}$ in Eq. (1) represents the diode

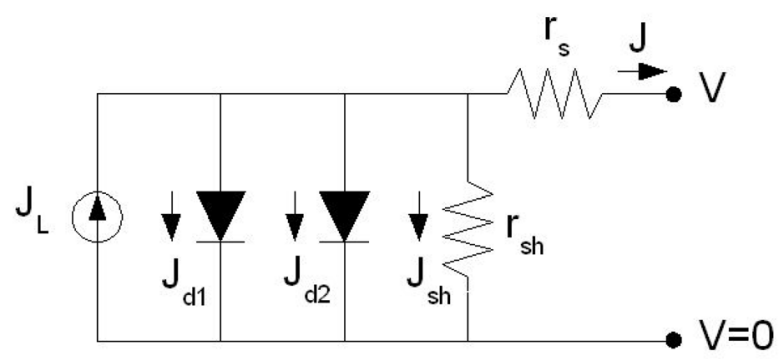

FIG. 2. An equivalent circuit of solar cell in the two-diode model. 
currents due to electron-hole recombination at the p-n interface of the solar cell, and it is given as [12]

$$
\mathrm{J}_{\mathrm{d} 2}=\frac{\pi \mathrm{n}_{\mathrm{i}} \mathrm{kTw}_{\mathrm{d}}}{\sqrt{\tau_{\mathrm{p}} \tau_{\mathrm{n}}}\left(\mathrm{V}_{\mathrm{b}}-\mathrm{V}^{\prime}\right)} \sinh \left(\frac{\mathrm{q} \mathrm{V}^{\prime}}{2 \mathrm{kT}}\right)=\mathrm{C}_{\mathrm{s}} \frac{\mathrm{kT}}{\sqrt{\mathrm{V}_{\mathrm{b}}-\mathrm{V}^{\prime}}} \sinh \frac{\mathrm{qV}^{\prime}}{2 \mathrm{kT}},
$$

where $n_{i}$ is the intrinsic carrier density, and $w_{d}$ is the width of the depletion region. $\tau_{\mathrm{p}}$ and $\tau_{\mathrm{n}}$ are the shortest lifetime of hole and electron, respectively, when all the recombination centers at the $\mathrm{p}-\mathrm{n}$ interface are filled with carriers of the opposite sign. It is noted that $\tau_{\mathrm{p}}=1 / \mathrm{N}_{\mathrm{t}}{ }^{-} \sigma \mathrm{v}_{\mathrm{p}, \mathrm{th}}$ and $\tau_{\mathrm{n}}=1 / \mathrm{N}_{\mathrm{t}}^{+} \sigma \mathrm{v}_{\mathrm{n}, \mathrm{th}}$, where $\mathrm{N}_{\mathrm{t}}^{-}$and $\mathrm{N}_{\mathrm{t}}^{+}$are densities of negatively and positively charged traps, respectively. $\sigma$ is the scattering cross section, and $\mathrm{v}_{\mathrm{p} / \mathrm{n}, \mathrm{th}}$ are the thermal velocities of hole/ electron, respectively. $\mathrm{qV}_{\mathrm{b}}$ is the energy difference between the conduction-band edges of the p-type and n-type semiconductors at zero bias. In this study, we assumed $\mathrm{V}_{\mathrm{b}}$ $=0.78 \mathrm{~V}$ for the CIGS solar cell. In Eq. (3), some properties can be merged into $\mathrm{C}_{\mathrm{s}}$ which represents the coefficient of $\mathrm{J}_{\mathrm{d} 2}$. Thus, there are five parameters, $\mathrm{J}_{\mathrm{L}}, \mathrm{J}_{\mathrm{s}}, \mathrm{C}_{\mathrm{s}}, \mathrm{r}_{\mathrm{s}}$, and $\mathrm{r}_{\mathrm{sh}}$ to be determined from the measured $\mathrm{J}-\mathrm{V}$ curve. We assume that these parameters do not depend on the bias voltage $\mathrm{V}$.

However, since the short-circuit current density $\mathrm{J}_{\mathrm{sc}}$ and the open-circuit voltage $V_{o c}$ can be determined easily from the experimental data, $\mathrm{J}_{\mathrm{L}}$ and $\mathrm{C}_{\mathrm{s}}$ are expressed as functions of $\mathrm{J}_{\mathrm{sc}}, \mathrm{V}_{\mathrm{oc}}, \mathrm{J}_{\mathrm{s}}, \mathrm{r}_{\mathrm{s}}$, and $\mathrm{r}_{\mathrm{sh}}$ :

$$
\mathrm{J}_{\mathrm{L}}=\frac{1}{1-\delta}\left[\mathrm{J}_{\mathrm{sc}}\left(1+\frac{\mathrm{r}_{\mathrm{s}}}{\mathrm{r}_{\mathrm{sh}}}\right)+\mathrm{J}_{\mathrm{s}} \mathrm{e}^{\frac{\mathrm{qJ}_{\mathrm{s}} \mathrm{r}_{\mathrm{s}}}{\mathrm{kT}}}-\frac{\delta \mathrm{V}_{\mathrm{oc}}}{\mathrm{r}_{\mathrm{sh}}}-\delta \mathrm{J}_{\mathrm{s}} \mathrm{e}^{\frac{\mathrm{qV}_{\mathrm{s}}}{\mathrm{kT}}}\right]-\mathrm{J}_{\mathrm{s}},
$$

where

$$
\delta=\frac{\sqrt{\mathrm{V}_{\mathrm{b}}-\mathrm{V}_{\mathrm{oc}}} \sinh \left(\frac{\mathrm{qJ}_{\mathrm{sc}} \mathrm{r}_{\mathrm{s}}}{2 \mathrm{kT}}\right)}{\sqrt{\mathrm{V}_{\mathrm{b}}-\mathrm{J}_{\mathrm{sc}} \mathrm{r}_{\mathrm{s}}} \sinh \left(\frac{\mathrm{qV} \mathrm{oc}}{2 \mathrm{kT}}\right)},
$$

and

$$
\mathrm{C}_{\mathrm{s}}=\frac{\sqrt{\mathrm{V}_{\mathrm{b}}-\mathrm{V}_{\mathrm{oc}}}}{\mathrm{kTsinh}\left(\frac{\mathrm{q} \mathrm{V}_{\mathrm{oc}}}{2 \mathrm{kT}}\right)}\left[\mathrm{J}_{\mathrm{L}}-\frac{\mathrm{V}_{\mathrm{oc}}}{\mathrm{R}_{\mathrm{sh}}}-\mathrm{J}_{\mathrm{s}}\left(\mathrm{e}^{\frac{\mathrm{q} \mathrm{V}_{\mathrm{c}}}{\mathrm{kT}}}-1\right)\right] .
$$

In order to fit Eq. (1) to the experimental result, we employ a numerical routine using three adjustable parameters, $J_{\mathrm{s}}, r_{\mathrm{s}}$, and $\mathrm{r}_{\mathrm{sh}}$. In particular, as initial guesses for $\mathrm{r}_{\mathrm{s}}$ and $r_{\text {sh }}$, we use $1 / r_{s}=|d J / d V|$ at $V=V_{\text {oc }}$ and $1 / r_{\text {sh }}=|\mathrm{dJ} / \mathrm{dV}|$ at $\mathrm{V}=0$ which are estimated from the experimental data.

\section{RESULTS AND DISCUSION}

Figure 3 displays some $\mathrm{J}-\mathrm{V}$ curves of the solar cell under different irradiation conditions from 1.5 through 5 -sun power density with a step of $1 / 2$-sun power density. The dots

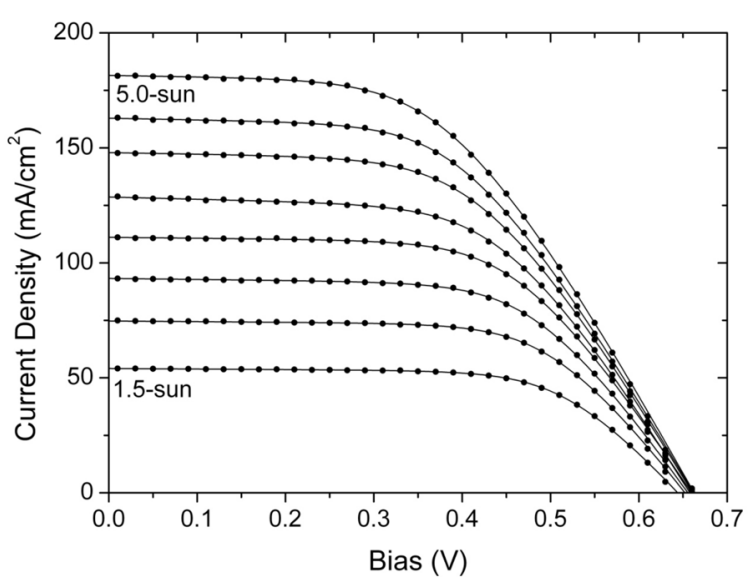

FIG. 3. Some J-V curves of the CIGS thin-film solar cell at different IPD from 1.5 through 5 sun with a step of $1 / 2$ sun. The dots represent the experimental data, whereas the curved lines represent the theoretical fits to the experimental results.

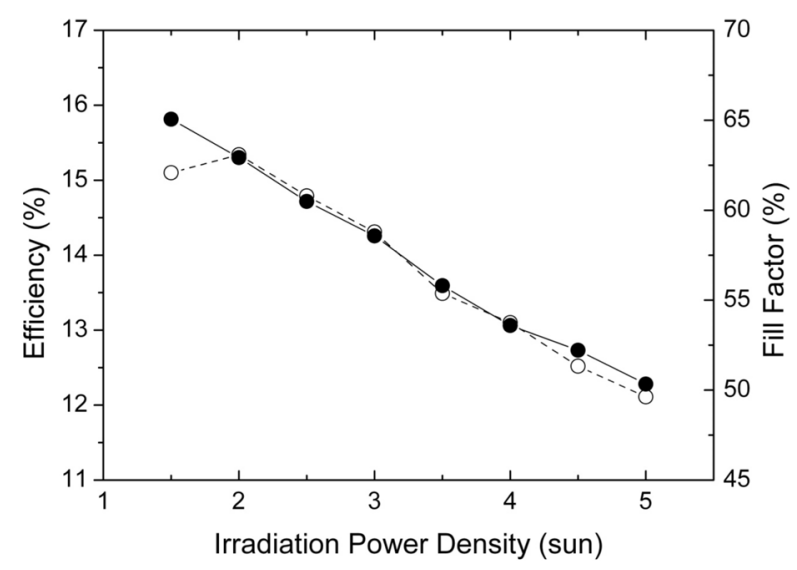

Fig. 4. The power-conversion efficiency and fill factor of the CIGS thin-film solar cell under different irradiation conditions. The open circles and the closed circles represent the powerconversion efficiency and the fill factor, respectively. The solid and dashes lines are guides to the eye.

represent the experimental data, whereas the lines are the best theoretical fits to the experimental results in the range of bias between zero and the open-circuit voltage of each curve. For the best theoretical fit, we mean that the results of the fit were obtained by computer using a standard minimization routine of functions. Figure 4 plots the power-conversion efficiency and fill factor of the solar cell versus IPD. For our solar cell, the fill factor decreased monotonically from $65.1 \%$ to $50.3 \%$ as IPD increases from 1.5 to 5 sun. The power conversion efficiency increased with IPD in the range from 1.5 to 2 sun, but it decreased monotonically in the range from 2 to 5 sun. The maximum power conversion efficiency was $15.3 \%$ at an IPD of 2 sun.

In the rest of this article, let us attempt to explain why the power conversion efficiency decreased as IPD increased. For all the irradiation conditions of the $\mathrm{J}-\mathrm{V}$ curve shown 
TABLE 1. List of parameters that are determined from the best fits of Eq. (1) to the experimental results shown in Fig. 1

\begin{tabular}{cccccc}
\hline \hline $\begin{array}{c}\text { Irradiation power density } \\
\left(\mathrm{kW} / \mathrm{m}^{2}\right)\end{array}$ & $\mathrm{r}_{\mathrm{s}}\left(\Omega \mathrm{cm}^{2}\right)$ & $\mathrm{r}_{\mathrm{sh}}\left(\Omega \mathrm{cm}^{2}\right)$ & $\mathrm{J}_{\mathrm{s}}\left(\mathrm{nA} / \mathrm{m}^{2}\right)$ & $\mathrm{C}_{\mathrm{s}}\left(\mathrm{mAV} / 1 / \mathrm{m}^{2}\right)$ & $\mathrm{J}_{\mathrm{L}}\left(\mathrm{mA} / \mathrm{cm}^{2}\right)$ \\
\hline 1.5 & 1.87 & 441 & 4.40 & 26.4 & 54.3 \\
2.0 & 1.62 & 348 & 4.24 & 31.9 & 75.1 \\
2.5 & 1.51 & 221 & 4.58 & 37.6 & 93.9 \\
3.0 & 1.44 & 248 & 4.52 & 42.3 & 112 \\
3.5 & 1.36 & 103 & 4.67 & 58.1 & 130 \\
4.0 & 1.33 & 147 & 3.90 & 72.2 & 149 \\
4.5 & 1.35 & 137 & 6.35 & 55.7 & 165 \\
5.0 & 1.26 & 157 & 4.09 & 89.5 & 183 \\
\hline
\end{tabular}

in Fig. 1, $\mathrm{r}_{\mathrm{s}}, \mathrm{r}_{\mathrm{sh}}, \mathrm{J}_{\mathrm{s}}, \mathrm{C}_{\mathrm{s}}$, and $\mathrm{J}_{\mathrm{L}}$ which were determined from fits are listed in Table 1. It should be noted that since there are five adjustable parameters to fit experimental results, the parameters extracted from the fit may not accurately represent the properties of the solar cell, but the set of parameters obtained from a number of experimental results with different experimental conditions may show the correct behaviors of the parameters. Therefore, a few results whose values deviated greatly from the general behavior may be considered to have a large uncertainty in the numerical fit. $\mathrm{J}_{\mathrm{L}}$ is nearly proportional to IPD, which is obvious in the linear optical regime. Js does not show any dependence on IPD. This result indicates that the diffusion coefficient, diffusion length, and surface recombination velocities of minority carriers do not depend on IPD. However, for our solar cell, $\mathrm{C}_{\mathrm{s}}$ is roughly proportional to IPD, implying that the density of the ionized traps which assisted electronhole recombination at the $\mathrm{p}-\mathrm{n}$ interface increased as IPD increased. Because $C_{s}$ is proportional to $\sqrt{\mathrm{N}_{\mathrm{t}}^{-} \mathrm{N}_{\mathrm{t}}^{+}}$, the density of diode current due to recombination at the $p-n$ interface might increase with IPD. This causes a negative effect on the open-circuit voltage and the power-conversion efficiency.

On the other hand, $r_{s}$ and $r_{s h}$ decrease as IPD increases. The similar behaviors of $r_{s}$ and $r_{s h}$ were observed with CIGS thin-film solar cell under irradiation with a power density less than one sun [10]. The behaviors of $r_{s}$ and $r_{s h}$ of the solar cell under different irradiation conditions indicate that the conductivity of the materials constituting the solar cell and the number of shunt-current paths increased with IPD. However, our results show that the relative decrease of $r_{\mathrm{sh}}$ is more rapid than that of $r_{s}$ as IPD increases from 1.5 to 5 sun. Since the density of defects plays an important role to determine the shunt resistance, we believe that an increase in the density of the ionized traps in the region of $\mathrm{p}-\mathrm{n}$ junction with the increasing IPD gave an additional contribution to the decrease of $r_{s h}$. This also provided one of reasons to reduce the fill factor and the power-conversion efficiency when IPD increases.

\section{CONCLUSION}

We have measured the $\mathrm{J}-\mathrm{V}$ curve of a CIGS thin-film solar cell under different irradiation conditions. Analyzing the $\mathrm{J}-\mathrm{V}$ curve using a two-diode model, we extracted the characteristic parameters of the solar cell. As IPD increased, the shunt resistance decreased more rapidly than the series resistance, whereas the coefficient of a diode current component due to electron-hole recombination at the $p-n$ interface increased. These were two of reasons why the power conversion efficiency and the fill factor of the solar cell decreased when IPD increased.

\section{ACKNOWLEDGMENT}

This work was supported by New \& Renewable Energy R\&D program (20103010010011) under the Ministry of Knowledge Economy, Republic of Korea. The work at KRISS was supported by the National Research Foundation (NRF) of Korea through a grant provided by the Korean Ministry of Education, Science and Technology (MEST) in 2007 (No. 2007-00011).

\section{REFERENCES}

1. M. A. Contreras, B. Egaas, K. Ramanathan, J. Hiltner, A. Swartzlander, F. Hasoon, and R. Noufi, "Progress toward 20\% efficiency in $\mathrm{Cu}(\mathrm{In}, \mathrm{Ga}) \mathrm{Se}_{2}$ polycrystalline thin-film solar cells," Prog. Photovolt: Res. Appl. 7, 311-316 (1999).

2. I. Repins, M. A. Contreras, B. Egaas, C. Dehart, J. Scharf, C. L. Perkins, B. To, and R. Noufi, "19.9\%-efficient $\mathrm{ZnO} / \mathrm{CdS} / \mathrm{CuInGaSe} 2$ solar cell with $81.2 \%$ fill factor," Prog. Photovolt: Res. Appl. 16, 235-239 (2008).

3. M. Kemell, M. Ritala, and M. Leskela, "Thin film deposition methods for CuInSe $\mathrm{C}_{2}$ solar cells," Critical Rev. Sol. St. \& Mat. Sci. 30, 1-31 (2005).

4. T. Todorov and D. B. Mitzi, "Direct liquid coating of chalcopyrite light-absorbing layers for photovoltaic devices," Eur. J. Inorg. Chem. 1, 17-28 (2010). 
5. Y.-D. Chung, D.-H. Cho, W.-S. Han, N.-M. Park, K.-S. Lee, and J. Kim, "Incorporation of $\mathrm{Cu}$ in $\mathrm{Cu}(\mathrm{In}, \mathrm{Ga}) \mathrm{Se}_{2}$-based thin-film solar cells," J. Korean Phys. Soc. 57, 1826-1830 (2010).

6. S. C. Kim and I. Sohn, "Simulation of energy conversion efficiency of a solar cell with gratings," J. Opt. Soc. Korea 14, 142-145 (2010).

7. S. M. Sze, Physics of Semiconductor Devices, 2nd ed. (John Wiley \& Son, New York, USA, 1981).

8. D. S. H. Chan and J. C. H. Phang, "Analytical methods for the extraction of solar-cell single- and double-diode model parameters from I-V characteristics," IEEE Trans. Elec. Dev. 34, 289-293 (1983).

9. S. S. Hegedus and W. N. Shafarman, "Thin-film solar cells: device measurements and analysis," Prog. Photovolt: Res. Appl. 12, 155-176 (2004).

10. A. Virtuani, E. Lotter, and M. Powalla, "Performance of $\mathrm{Cu}(\mathrm{In}, \mathrm{Ga}) \mathrm{Se} 2$ solar cells under low irradiance," Thin Solid Films 431-432, 443-447 (2003).

11. Y. D. Chung, W. S. Han, S. B. Bae, N. M. Park, D. H. Cho, K. S. Lee, S. Y. Oh, and J. Kim, "Fabrication and characterization of $\mathrm{Cu}(\mathrm{In}, \mathrm{Ga}) \mathrm{Se}_{2}$ thin-film solar cell minimodules," in Proc. 19th International Photovoltaic Science and Engineering Conference (PVSEC19) (International Convention Center, Jeju, Korea, 2009), p. 262.

12. M. J. Grigg, B. M. Kayes, and H. A. Atwater, "P-n junction heterostructure device physics model of a four junction solar cell," Proc. SPIE 6339, 63390D (2006). 